\title{
SPECIES AND TISSUE DIFFERENCES IN THE CATABOLISM OF S-ADENOSYL-L-HOMOCYSTEINE: A QUANTITATIVE, CHPOMATOGRAPHIC STUDY
}

\author{
R. A. Schatz, Chouda Rant Vumam and 0. Z. Sellinger
}

Laboratory of Neurochenfstry, Mental Health Research Inst1tute, University of Michigan, Ann Arbor. Michigan 48109

(Recelved in final form December 10, 1976)

\section{SUMARY}

Using apld, quantitative high pressure 11quid chromatographlc (HPLC) procedure for the separation of S-adenosyl-L-homocysteine (AdoHcy) and its purinic metabolites in rat and mouse brain, kidney and liver, we found that uric acid is the principal catabollc product of AdoHcy metabolism in the liver, but that none forms in brain. Rat kidney formed about 10 times as much uric acid and half as much hypoxanthine as did mouse kidney. The HPLC procedure has been adapted to assay AdoHcy hydrolase activity which was found to be lowest in the brain and highest in the liver.

The ab1lity of S-adenosyl-L-homocysteine (AdoHcy) to Inhtbit the activity of histamine-N-methyl transferase $(1,2)$, catechol-0-methyltransferase (3). Indolethyl amine-N-methyl transferase (4), tRNA methyl transferase $(5,6)$ and phenylethanolamine- $N$-methyltransferase (7) has led to much interest in the role of AdoHcy as a regulator of methylation processes. The enzyme responsible for AdoHcy hydrolysis (AdoHcy hudrolase, E.C. 3.3.1.1.) (8) may thus be crucial in the regulation of tissue AdoHcy levels (8-i1), and hence of cellular transmethylation. In vitro AdoHcy hydrolase is inhibited by the end products of the hydrolytic reaction homocysteine (Hcy) and adenosine (Ado). Ado is further metabolized to inosine (Ino), hypoxanthine (Hyp), xanthine (Xan) and, in liver, to urfc actd (12).

Previously described methods for the separation of AdoHcy from Its purinic metabolites are rather time consuming as they require column $(9,13$, 14), paper $(8,10,12,13)$ or thin layer (15) chromatographic procedures foliowed by an independent quantitative determination of each separated metabolite. The most rapid separation takes $2.5 \mathrm{~h}$ using low voltage paper electrophoresis (16). The development of high pressure 11quid chromatography (HPLC) has greatiy decreased the time necessary for separation and analysis of many substances. Indeed, an HPLC method requiring less than 30 min for the separation and quantitation of several purines has recently been described (17). We report a rapld and factle method, also using reverse phase HPLC, for the separation and quantitation of nanogram amounts of AdoHcy and its purinic metabolites and requiring only 6-8 min for each sample. The method has been applied to the quantitation of the purinic metabolites formed by incubating AdoHcy with soluble extracts of rat and mouse liver, kidney and brain tissue and for an assay of AdoHcy hydrolase. 


\section{MATERIALS AND METHODS}

Apparatus. A $\mu$ Bondapak $C_{1}$ (a non-polar material consisting of a monomolecular layer of octadecyltriehlorosilane) column (30 cm $\times 0.4 \mathrm{~cm} \mathrm{I}$. D. for reverse phase chromatography was obtained from Waters Associates, Inc. Milford, MA). A solvent delivery system equipped with dual piston pump (model $6000 \mathrm{~A}$ ), a universal 11quid chromatography injector (model U6K) and an absorbance detector (model 440) were also from Waters Assoctates. The chromatographic runs were recorded on an Omintscribe recorder (Texas Instruments, Austin, $\mathrm{TX})$. In some cases, fractions $(0.12 \mathrm{ml})$ from chromatographic runs were collected using an LKB fraction collector (model 7000, LKB Instruments, Chicago, IL).

Reagents. Adenosine, inosine, hypoxanthine, xanthine, uric actd, S-adenosyl-L-homocystetne, 6-methylamino-9-rlbofuranoside (MAPR) and adenosine deaminase (adenostne aminohydrolase, E.C. 3.5.4.4, Type I from calf intestinal mucosa) were obtained from Sigma Chemtcal (St. Louis, MO). D,L-homocyst ty ne (free base) was from ICN Nutritional Blochemfcals (Cleveland, $\mathrm{OH}$ ) and [8- $\left.{ }^{4} \mathrm{C}\right]$ adenosine (sp. act. $52 \mathrm{mC1} / \mathrm{mmol}$, from New England Nyglear (Boston, MA). Radioactive [8- $\left.{ }^{4} \mathrm{C}\right]$ AdoHcy was prepared from $\mathrm{Hcy}$ and $\left[8-{ }^{4} \mathrm{C}\right]$ adenosine in the presence of the adenosine deaminase inhibitor MAPR (11) using a dialyzed high speed supernatant $(100,000 \mathrm{~g} \times 35 \mathrm{~min})$ from rat brain as a source of AdoHcy hydrolase. After a $2 \mathrm{~h}$ incubation at $37^{\circ} \mathrm{C}$ the reaction was stopped by addition of $4 \mathrm{~N}$ perchloric actd. The sample was then neutralized by addition of $1 \mathrm{~N} \mathrm{KOH}$ and filtered (0.45 pHetricel filter). The filtered solution was injected onto a $\mu$ Bondapak $\mathrm{C}_{18}$ column and the AdoHcy fraction collected (see Chromatographic separation for detafls). The radioactive AdoHcy was placed on a Dowex 50 column $\left[\mathrm{H}^{+}\right.$] equilibrated with $1 \mathrm{~N} \mathrm{HCl}$, after which the column was eluted with water followed by $3 \mathrm{~N} \mathrm{NH}_{4} \mathrm{OH}$ (14). The $\mathrm{NH}_{4} \mathrm{OH}$ fraction contains AdoHcy and this step was performed to free AdoHcy froin the HPLC buffers. Finally, the AdoHcy fraction was lyophilized and its specific activity adjusted to $0.27 \mathrm{mCl} / \mathrm{mmol}$ by dilution with non-radloactfve AdoHcy.

Chromatographic separation. Varying allquots of a standard solution containting AdoHcy, Ado, Ino, Hyp, Xan and urtc actd (45 $\mu \mathrm{g} / \mathrm{ml}$ of each) were applfed to a $\mu$ Bondapak $C_{3}$ column via the injector septum at room temperature using a $100 \mu$ i syringe (Prectsion Sampling Corp., Baton Rouge, LA) at a constant flow rate (buffer 1 ) of $2 \mathrm{ml} / \mathrm{mln}$. Buffer 1 was $0.04 \mathrm{M}$ dibasic amonium phosphate $(5 \%, v / v$ methanol, $\mathrm{pH} 8.0)$ and buffer 2 was $0.04 \mathrm{M}$ monobasic ammonium phosphate $(20 \%, v / v$ methanol, $\mathrm{pH} \mathrm{4.7)}$. There was a lag of $8.4 \mathrm{ml}$ between buffer changes and their appearances on the spectrophotoneter tracing. In Initial experiments elution with buffer 2 was begun $1.25 \mathrm{~min}(2.5 \mathrm{ml})$ after sample injection. Subsequently we found that sample injection, $0.5 \mathrm{~min}$ after beginning elution of the column with buffer 2, reduced the time necessary for separation of each sample (see Figures 1 and 3 for detailed chronology of elution). Both buffers and all samples were filtered $(0.45$ Metricel filter) prior to use. In addftion, buffers were degassed in vacuo before use.

Animals, tissue preparation and enzyme assay. Adult male Sprague-Dawley rats $(120-200 \mathrm{~g})$ and Swiss-Hebster mice (25-30 g) (Spartan Research Animals, Haslett, MI) were sacrificed by decapitation, af ter which brain, kidney and 1 iver were rapidly excised, rinsed with buffer $(0.05 \mathrm{M}$ potasstum phosphate, pH 7.4), blotted and weighed in tared beakers containing buffer. Tissues were homogenized in 5 vol buffer, centrifuged at $100,000 \mathrm{~g} \times 35 \mathrm{~min}$ and the supernatants dialyzed against three changes of buffer $(0.005 \mathrm{M}$ potass 1 um phosphate, pH 7.4). The AdoHcy hydrolase reaction mixture contained $50 \mathrm{nmol}\left[8-{ }^{2} \mathrm{C}\right]$ AdoHcy $(119 \mu \mathrm{M}), 0.1 \mathrm{ml}$ dialyzed supernatant and 0.051 units of adenosine deaminase in phosphate buffer $(0.05 \mathrm{M}, \mathrm{pH} \mathrm{7.4)}$ (total vol.: $0.31 \mathrm{ml}$ ). Blanks con- 
tained heated supernatant $\left(5^{\circ} \mathrm{min}, 95^{\circ} \mathrm{C}\right)$. The reaction $\mathrm{mixtures}$ were incubated at $37^{\circ} \mathrm{C}$ for $15 \mathrm{~min}$ after which the reaction was stopped by addition of $15 \mu 1$ of $4 \mathrm{~N}$ perchloric acid. Samples were than neutralized with $60 \mu 1$ of $1 \mathrm{~K} \mathrm{KOH}$, diluted with water (final vol.: $0.54 \mathrm{ml}$ ), and filtered. An allquot of $90 \mathrm{pl}$ was injected onto the Bondapak column 30 sec after changing from elution with buffer 1 to elution with buffer 2 (see Flgure 3 for detalled chronology of elution).

\section{Quantation of AdoHcy, and Metabolites}

Absorbance. Standard curves of AdoHcy and its purinic metabolites mere constructed by comparing known amounts of standards to the maximum peak helght $\left(A_{254}\right)$ produced by each compound. These data were then analyzed by linear regression analysis. For quantitation of enzyme reaction inixtures, the change in peak helght absorbance of sainples, compared to blanks, was deternined followed by compartson of these values with those of standards mun the saine day.

Radionetric. Colum eluates mere collected $(0.12 \mathrm{mi}$ fractions) directly into scintillation vials and, after addition of 2 inl PCS (a tissue solubilizerscintillation mixture, Searle Analytic, Arlington Heights, IL), the semples were counted. Counting efficlency was deternined using the channels ratio method. The total radioactivity in each sample peak was compared to its blank and this difference used to determine the amount of AdoHcy remaining or the anoynt of metabolite formed by calculation from the speciflc activity of $\left[8-{ }^{4} \mathrm{C}\right]$ AdoHcy $(0.27 \mathrm{mC1} / \mathrm{mmol})$.

\section{RESULTS AND DISCUSSION}

Figure 1 represents a typical reverse phase HPLC separation of a standard mixture of AdoHcy and Its purinic metabolites. The compounds, in their ordar of elution, are uric acid, Xan. Hyp, Ino, AdoHcy and Ado. Buffer 1, alone, resolved all the above compounds, however, the retention volumes of Ino, AdoHcy and Ado were increased and thefr respective peaks becane quite braod, making peak height measurements $\left(A_{2}\right)$ tnaccurate. Buffer 2, on the other hand, cleanly resolved Ino, AdoHcy 8 ind Ado with a much higher peak absorbance than buffer 1 , but $X$ an and Hyp were not resolved and appeared as one poak. The combination of buffers 1 and 2, however, provided a rapid separation paired with the maximum peak helghts attainable for each individual conipound. The order of elution of uric acid, Xan and Hyp is different than previousiy reported (17) in that Hyp eluted before Xan, however, the elution sequence shown in Figure 1 is as would be predicted from the pK values of the individual compounds $(5.75,7.7$ and 8.8 , respectively). That solvent affinity of the vartous compounds also plays a role in this separation was indicated by the poor resolution of uric acid, Xan and Hyp seen after decreasing the polarity (methanol concentration increased from 5\% to 20\%) of the moblle phase (buffer 1). The pK values of Hyp and Ino are quite close ( 8.8 and 8.85 , respectively) and separation of these compounds is effected by decreasing the pH of the mobile phase from 8.0 to 4.7 at a point prectsely between the retention volumes of Hyp and Ino. Ino is less polar at pH 4.7 and is consequentiy ratained longer on the stationary phase of the colunm. Addition of the anino ac1d substituent (Hcy) to Ado results in increased polarity of the resultant compound (AdoHcy) compared to Ado as evidenced by their elution order (AdoHcy followed by Ado) ( $\mathrm{FIg} .1)$. Ado eluted last in this serles inich generally agrees with another HPLC study (17) in which, of 23 related compounds tested, only one, cMP, eluted after Ado. Solvent affinity also plays a role in the separation of Ino, AdoHcy and Ado as evidenced by the fact that reducing the methanol concentration of buffer 2 (from 20\% to 5\%) markedly extended the retention time of these compounds (espectally AdoHcy and Ado) al though their elution order remained unchanged (Schatz and Sellinger, unpubilshed work). 


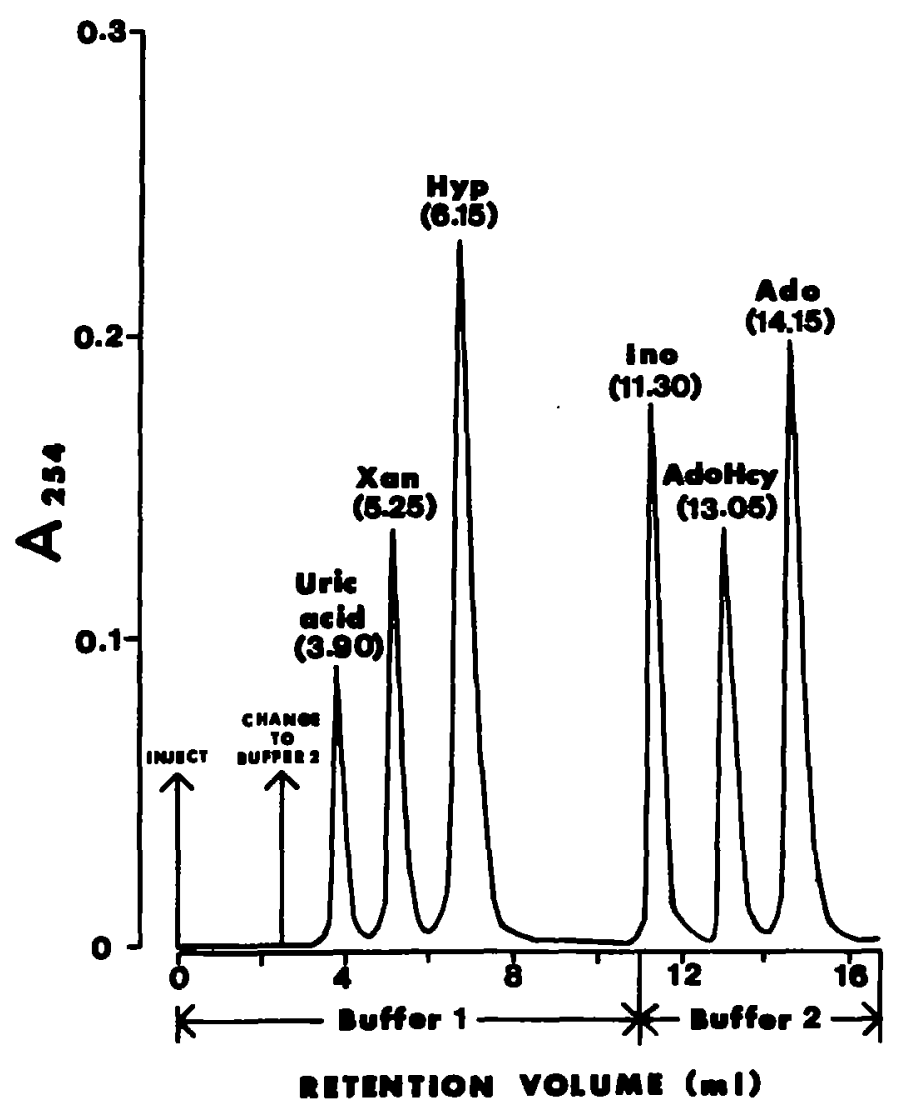

FIG. 1

Reverse phase HPLC separation of a standard mixture of AdoHcy and its purinic metabolites. A $75 \mu 1$ aliquot of a standard mixture containing $3.375 \mu \mathrm{g}$ each of AdoHcy, Ado, Ino, Hyp, Xan and uric acld was injected onto a $\mu$ Bondapak $C_{1}$ column at a flow rate of $2 \mathrm{ml} / \mathrm{min}$. Buffer 1 was $5 \%(\mathrm{v} / \mathrm{v})$ methahiol in $0.04 \mathrm{M}$ dibasic anmontum phosphate (pH 8.0; pressure, 2500 psi) and buffer 2 was 20\% (v/v) methanol in 0.04 monobastc ammonium phosphate ( $\mathrm{pH} 4.7$; pressure, 3000 psi).

The linearity of the spectrophotometric response over a 40-fold range of increasing amounts of standard (FIg. 2) demonstrates the rellability and reproducibility of absorption measurements for the quantitative determination of AdoHcy and of its purinic metabolites. The sensitivity of this method allowed detection of amounts as low as $180 \mathrm{ng}$. Absorption measurements of lesser amounts of standards were complicated by the fact that the baseline increased 
slightly with buffer 2 and this increase becane greatly amplified at low detector sensitivity settings, making true peak height determination difficult and of doubtful accuracy.
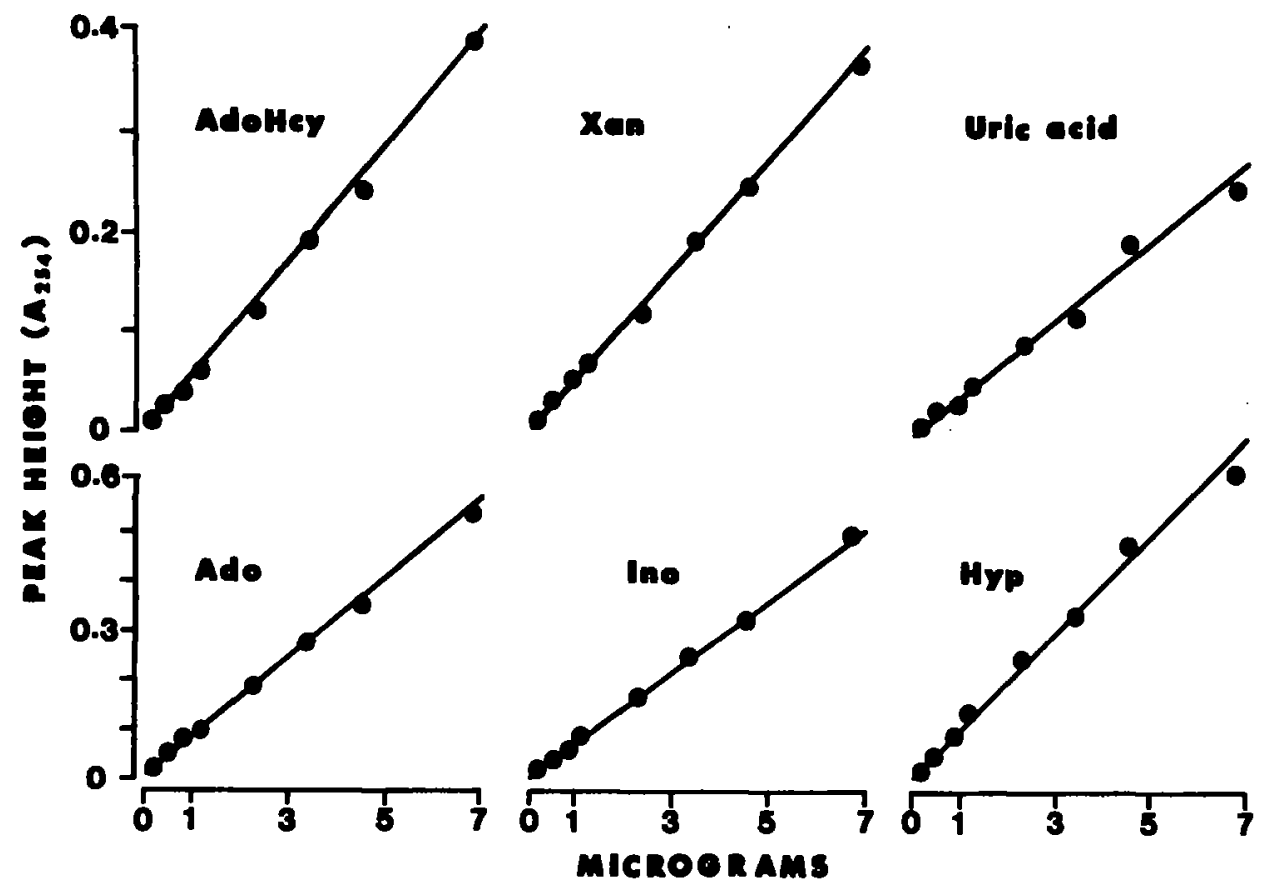

FIG. 2

Standard curves of a mixture of AdoHcy and its purinic metabolites. Aliquots, in triplicate (varlation less than 5\%), of a standard mixture containing $45 \mathrm{\mu g} / \mathrm{ml}$ each of AdoHcy, Ado, Ino, Hyp, Xan and uric acid were injected onto a $u$ Bondapak column at a flow rate of $2 \mathrm{~m} 1 / \mathrm{min}$. Time of sample injection and buffer change were as in F1g. 1. Peak height values were determined by multiplying the maximum absorbance $\left(A_{25}\right)$ by the approprlate detector sensitivity setting. The correlation coeffictent $(r)$ was at least 0.99 for all compounds. Also, a test of the hypothesis $(r=0)$ was rejected in all cases.

Figure 3 is an elution profile of an AdoHcy hydrolase reaction mixture using rat brain as the source of enzyme. In all tissues examined (Table 1 and Fig. 3). retention volumes of peaks of radioactivity corresponded exactly to prevfously determined retention volumes of "cold" standards. Recovertes from the Bondapak column were from 96-100\% and AdoHcy or its purinic metabolites accounted for all of the radioactivity present in the injected sample. Table 1 shows that hydrolysis of AdoHcy proceeded most rapidiy in liver followed by kidney and brain, respectively. Generally, ifttle interspectes difference 


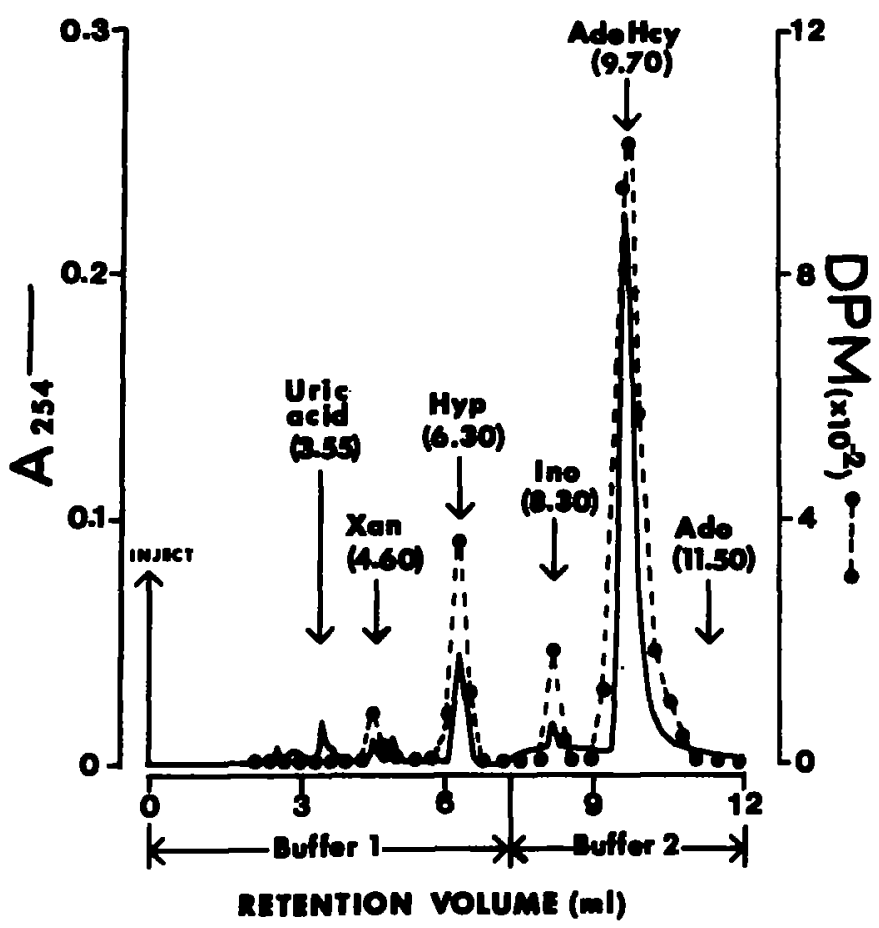

FIG. 3

Reverse phase HPLC of AdoHcy and 1ts purinic metabolites in rat brain. A 90 il al iquot of an AdoHcy hydrolase reaction mixture was injected onto a $\mu$ Bondapak column at a flow rate of $2 \mathrm{ml} / \mathrm{min}$, $30 \mathrm{sec}$ after changing to buffer 2. Buffers 1 and 2 are described In Methods. Solld ine denotes absorbance $\left(A_{254}\right)$ and dotted ilne denotes DPMs. Fractions $(0.12 \mathrm{ml})$ were collected directly into scintillation vials and counted after addition of $2 \mathrm{ml}$ of scintillant. Arrows and numbers in parentheses indicate retention volumes of a standard solution containing AdoHcy and its purinic metabo11tes. Note that retention volumes are different in Fig. 1 owing to the different lag time between changing of buffers and injection of sample.

(Table 1) existed in the extent of AdoHay hydrolysis for a given tissue, however, hydrolysis was somewhat greater in rat brain than in mouse brain. In both rat and mouse brain Ino and Hyp represented most of the AdoHcy hydrolytic products, with very little Xan and no uric acid being detected. In rat and mouse liver, $83 \%$ and $91 \%$ respectively, of the AdoHcy mas converted to uric actd. In rat kidney, the distribution of AdoHcy hodrolytic products was found to be relatively even between uric acid (31\%), Xan (27\%), Hyp (26\%) and Ino (15.5\%) whereas, in mouse kidney, most of the AdoHcy was converted to Ino (26\%) and Hyp (54.5\%), 16.5\% to xanthine and less than $4 \%$ to urtc actd.

The formation of Hyp in all tissues tested (Table 1) confirmas the presence of inos ine-guanos ine phosphorylase (E.C. 2.4.2.1; 2.4.2.15) intle the formation of Xan or uric actd Implies that of xanthine oxidase (E.C. 1.2.3.2). As the Adoltcy incubations were conducted in the presence of an excess of 
TABLE 1

Conversion of AdoHcy to purinic metabolites in rat and nouse tissues

\begin{tabular}{lccccc} 
TIssue & Uric acid & Xan & $\begin{array}{c}\text { nanomoles } \\
\text { Hyp }\end{array}$ & Ino & AdoHay \\
\hline Rat brain & 0 & 1.9 & 7.5 & 2.6 & 37.9 \\
Mouse brain & 0 & 0.6 & 3.9 & 3.4 & 42.1 \\
Rat IIver & 41.7 & 0 & 0 & 3.4 & 4.8 \\
Mouse IIver & 45.3 & 1.4 & 0.4 & 0.5 & 2.3 \\
Rat kIdney & 8.3 & 7.1 & 6.8 & 4.1 & 23.6 \\
Mouse kidney & 0.8 & 4.7 & 15.5 & 7.3 & 21.5 \\
\hline
\end{tabular}

a The data show the distribution of AdoHcy and 4 its purinic metabolites after reaction (15 min) of $50 \mathrm{nmol}$ AdoHcy [8- ${ }^{4} \mathrm{C}$ ] with $0.1 \mathrm{ml}$ dfalyzed high-speed supernatant (see Methods) In the presence of excess Intestinal adenosine deculnase. Values were cal culated as described in Methods. Recovertes fran the Bondapak colum varled from 96-100\% and the values are corrected accordingly.

Intestinal adenosine deaninase, no direct conclusions can be made concerning the presence of this enzyrie, however, the presence of adenosine deaninase has been demonstrated in the brain, kidney and liver of the rat and the mouse (18). Preliminary experinents in our laboratory (Schatz and Sellinger, unpublished work) have damonstrated the feasfbility of using the IPLC separation procedure for the separate assay of adenosine desainase, purine-nucleoside phosphorylase $(18,20)$ and xanthine oxidase $(21)$, by using the approprlate substrate and by meeting the different $\mathrm{pH}$ and cofactor requirenents for each enzyme. Table 2 shows the usefulness of the described HPLC method of separation and quantitation as an assay for AdoHcy hydrolase. As may be seen data obtained by absorbance or radiometric measurements were in close agreement. Comparison of the AdoHcy hydrolase activity with literature values is complicated by the use of different buffers, $\mathrm{pH}$ and assay conditions; howevor, the present values are in the same range as previously reported values $(9,14)$. Further, comparison of AdoHcy hydrolysis between tissues (Table 2) showed hydrolysis to be fastest in 1 iver followed by $k 1$ dney and brain as has been reported $(9,14)$. Values for AdoHcy hydrolase in liver are (Table 2) probably an underestimate as most of the substrate (AdoHcy) was consuned during incubation (Table 1). Indeed, further expertments were conducted using less Ifver enzyme and AdoHcy hydrolase activity was found to be 12.9 and 16.1 unol AdoHcy hodrolyzed/g tissue/15 min in mouse and rat 1Iver, respectively (see Table 2, footnote b). 
TABLE 2

Comparison of AdoHcy hydrolase activity in 3 tissues of rat and mouse

AdoHcy hydrolase ${ }^{\mathrm{a} .}$

\begin{tabular}{lcc} 
Tissue & Absorbance & DPM \\
\hline Rat brain & 0.68 & 0.72 \\
Mouse brain & 0.40 & 0.45 \\
Rat liver ${ }^{b .}$ & 2.74 & 2.71 \\
Mouse liver & 2.83 & 2.87 \\
Rat kidney & 1.47 & 1.58 \\
Mouse kidney & 1.73 & 1.72 \\
\hline
\end{tabular}

a.AdoHcy reaction mixtures were as described (Methods or Table 1). Enzyme activity (umol AdoHcy hydrolyzed/g tissue/15 min) was calculated as AdoHcy disappearance on the basis of peak helght $\left(A_{25}\right)$ or total DPM in the AdoHcy peak. Absorbance measurements represent averages of triplicate samples, whereas DPM measurements represent averages of duplicate samples (variation less than 5\%).

b. The liver values were determined under conditions of excess substrate consumption, and are thus an underestimate. In the presence of $0.01 \mathrm{ml}$ Instead of $0.1 \mathrm{ml}$ (see Methods) enzyme, AdoHcy hydrolase activity was 12.9 and 16.1 umol AdoHcy hydrolyzed/g tissue/15 min in mouse and rat ilver, respectively, using peak height $\left(A_{254}\right)$ measurements to determine activity.

In conclusion, a reverse phase HPLC method is described for the separation of AdoHcy and its purinic metabolites. This method may be used for the routine determination of the activity of AdoHcy hydrolase. An added advantage is that radfoactive AdoHcy is not necessarily required.

\section{ACKNONLEDGEMENT}

Supported by grant NINCDS 06294 from the Untted States Public Health Service.

\section{REFERENCES}

1. V. ZAPPIA, C. R. ZYDEK-CWICK and F. SCHLENK, J. B101. Chem., 244:44994509 (1969).

2. M. BAUDRY, F. CHAST and J. C. SCHWARTZ, J. Neurochem., 20:13-21 (1973).

3. J. K. COWARD, M. D'URSO-SCOTT AND W. D. SWEET, Btochem. Pharmacol., 21: 1200-1203 (1972).

4. R. L. LIN and N. NARASIMHACHARI, Blochem. Pharmacol., 24:1239-1240 (1975).

5. A. E. PEGG, FEBS Letters, 16:13-16 (197/).

6. J. M. GLICK, S. ROSS and P. S. LEBOY, Nucleic Acids Res.., 2:1639-1651 (1975).

7. T. DEGUCHI and J. BARCHAS, J. B101. Chem., 246:3175-3181 (1971).

8. G. DE LA HABA and G. L. CANTONI, J. BToT. Chen., 234:603-608 (1958).

9. R. D. WALKER AND J. A. DUERRE, Cañ. J. Biochem., 53:312-319 (1975). 
10. R. A.- SCHATZ, C. R. VUAMAM and O. Z. SELLIMGER, Meurochem. Res., in press (1977).

11. J. D. FINKELSTEIN and B. HARRIS, Arch. B10chem. B1ophys., 171:282-286 (1975).

12. R. CORTESE, E. PERFETTO, P. ARCARI, G. PROTA and F. SALVATORE, Int. J. Blochem., 5:535-545 (1974).

13. M. K. GAITONDE and G. E. GAULL, Btochem. J., 102:959-975 (1967).

14. J. D. FINKELSTEIN and B. HARRIS, Arch. BTochem. Btophys., 159:160-165 (1973).

15. J. E. POULTON and V. S. BUTT, Arch. Blochen. Biophys.. 172:135-142 (1976).

16. 0. KAJANDER, T. ELORANTA and A. RAINA, BTochim. BTophys. Acta., 438: 522-531 (1976).

17. F. S. ANDERSON and R. C. MURPHY, J. Chromatog., 121:251-262 (1976).

18. T. G. BRADY and C. I. O 'DONOVAN, Comp. BTochem. Physiol., 14:101-120 (1965).

19. V. SCHULTZ and J. M. LOWENSTEIN, J. B101. Chen., 251:485-492 (1976).

20. A. Y. DIVEKAR, B tochim. Btophys, Acta., 422:15-28 (1976).

21. H. KIUGE, W. HARTIWNN, W. ZARLTEN and U. RING, J. Chromatog., 56:365-367 (1971). 